\title{
Pine Bark Substrates Amended with Parboiled Rice Hulls: Physical Properties and Growth of Container-grown Spirea during Long-term Nursery Production
}

\author{
Celina Gómez ${ }^{1,3}$ and James Robbins ${ }^{2}$ \\ Department of Horticulture, University of Arkansas, 2301 S. University Avenue, \\ Fayetteville, AR 72701
}

Additional index words. alternative substrate, growing media, soilless media

\begin{abstract}
The decline in the availability of pine (Pinus taeda L.) bark (PB) supplies and increasing prices have caused concerns in the nursery industry. Research was conducted to evaluate the effect of parboiled rice (Oryza sativa $\mathrm{L}_{\text {.) }}$ hulls $(\mathrm{PBH})$ as a substrate amendment to PB-based container substrates on the growth of Spiraea $\times$ bumalda L. 'Anthony Waterer' and to examine the changes in physical properties of the substrates during long-term production cycles under outdoor nursery conditions. Six substrates were formulated by blending PB with $0 \%, 20 \%, 40 \%, 60 \%, 80 \%$, or $100 \%$ PBH (by volume). Substrate composition affected plant growth components evaluated, generally decreasing growth as the amount of PBH increased. However, amending PB with up to $40 \%$ PBH did not result in a significant decrease in plant growth or increase the volume or frequency of irrigation for container-grown spirea. Physical properties of substrates amended with PBH improved over time. Based on these results, PB-based substrates amended with up to $40 \%$ PBH retained physical properties that were generally within current guidelines for nursery container substrates after one ( 25 weeks) and two (70 weeks) growing seasons.
\end{abstract}

The most common components of soilless container media used by the nursery industry in the United States are bark from loblolly pine (Pinus taeda L.) and douglas fir [Pseudotsuga menziesii (Mirb.) Franco]. Loblolly $\mathrm{PB}$ is widely used by growers on the East Coast, in the Midwest, and in the southern regions of the United States and douglas fir bark is commonly used on the West Coast. Within the last decade, the nursery industry has faced a steady decline in the availability of PB as well as higher costs because of an increase in demand for alternative uses (e.g., heating fuel), a decline in log harvest, and an increase in freight costs (Haynes, 2003; Lu et al., 2006). A greater shortage and inferior quality of $\mathrm{PB}$ are expected as a result of the increasing demand for wood-based materials to be used as biofuels (Day, 2009). The industry is interested in alternative, economical, and sustainable container substrates that are able to provide adequate growing conditions for nursery production.

Received for publication 31 Jan. 2011. Accepted for publication 15 Mar. 2011.

This research was funded in part by Riceland Foods, Inc. Stuttgart, AR. Pine bark provided by Sun Gro Horticulture, Pine Bluff, AR.

Assistance from Douglas Karcher, David Hensley, and Leonel Espinoza is gratefully acknowledged. ${ }^{1}$ Former graduate student.

${ }^{2}$ Professor

${ }^{3}$ To whom reprint requests should be addressed; e-mailcelinagomezv@gmail.com.
To address this issue, a long list of bark alternatives has been evaluated, including but not limited to pine trees/wood (Boyer et al., 2008; Fain et al., 2008; Jackson, 2008; Jackson et al., 2009; Wright and Browder, 2005; Wright et al., 2006), recycled paper (Craig and Cole, 2000), composted turkey litter (Tyler et al., 1993), cotton gin waste (Cole et al., 2005; Jackson et al., 2005; Owings, 1993), and sewage sludge (Guerrero et al., 2002). Other new materials currently being evaluated as substitutes for PB in nursery production include some fast-growing herbaceous crops such as switchgrass, willow, corn, and bamboo (Boyer et al., 2010).

Another possible alternative is rice (Oryza sativa L.) hull. Rice hulls are a relatively underused and sustainable container substrate, which are normally considered a waste byproduct of the rice milling and processing industry (Lovelace and Kuczmarski, 1992). Large quantities of rice hulls are produced annually in the United States, especially in the southern and western states. Numerous studies have been conducted evaluating different forms of rice hulls as alternative substrates in propagation, greenhouse, and nursery production. Rice hulls are available in a variety of forms, including fresh, aged, carbonized, composted, burnt, and parboiled (Buck, 2008). Fresh rice hulls are typically avoided as container substrates because of residual rice and/or weed seed.

Parboiled rice hulls are produced by steaming and drying rice hulls after the milling process. This results in a lightweight and consistent product that is free of viable weed and/or rice seed (Evans and Gachukia, 2004). Another advantage in using PBH as a horticultural substrate amendment is the low decomposition rate during the typical production cycle of nursery crops. Despite being an organic compound, rice hulls consist mainly of lignin, cutin, and insoluble silica, providing a slow breakdown of particles and therefore making $\mathrm{PBH}$ an appropriate substrate for longterm crop production (Juliano et al., 1987).

Einert and Guidry (1975) published some of the earliest work on the use of fresh and composted rice hulls as an amendment for the soil-based container production of woody ornamentals. Although statistical analyses were not included, either form of rice hulls appeared to be a suitable media amendment based on mortality and growth data for Pfitzer juniper [Juniperus $\times$ pfitzeriana (L.) Späth]. Laiche and Nash (1990) evaluated the effect of composted rice hulls on the growth of three woody plants (Rhododendron indicum L., Ilex crenata Thunb., and Juniperus horizontalis Moench.) in containers. Their results demonstrated plant growth in organic components of $100 \%$ composted rice hulls or $50 \%$ composted rice hulls:50\% bark compared favorably with the growth obtained using $100 \%$ PB.

Lovelace and Kuczmarski (1992) reported that aged rice hulls compared favorably to $100 \% \mathrm{~PB}$ in cost and performance when used as a component of a blend including $\mathrm{PB}$, rice hulls, and sand ( $2: 2: 1$ by volume) for a variety of woody ornamentals. Baiyeri (2005) demonstrated that when using composted rice hulls amended with poultry manure $(3: 1$ by volume), sucker plantlets from five banana genotypes generally resulted in more vigorous suckers than when sawdust and poultry manure ( $3: 1$ by volume) or rice hulls, sawdust, and poultry manure (1.5:1.5:1 by volume) were used at the nursery stage of production.

Fresh (Einert, 1972; Papafotiou et al., 2001; Sambo et al., 2008), carbonized (Kämpf and Jung, 1991; Tatum and Winter, 1997), parboiled (Evans and Gachukia, 2007), and ground parboiled (Buck and Evans, 2010) rice hulls have been evaluated as substrates on a number of greenhouse crops. Dueitt and Newman (1994) determined that fresh rice hulls hold more water than aged rice hulls in greenhouse media for seedlings of Tagetes erecta L. and Limonium suworowii (Reg.) Kuntze. Evans and Gachukia (2007) reported that the large particles of $\mathrm{PBH}$ provide adequate drainage and aeration in peat-based substrates. More recently, Buck and Evans (2010) revealed that given its physical properties, ground $\mathrm{PBH}$ can be used as a suitable replacement for up to $40 \%$ peatmoss to grow greenhouse crops.

A preferred container substrate should provide stable plant support, a reservoir for nutrients and water to the root system, and adequate gas exchange (Nelson, 2003). Bunt (1988) stated that the most important physical properties of containerized substrates are dry bulk density (DBD; $\left.\mathrm{g} \cdot \mathrm{cm}^{-3}\right)$, air-filled pore space (AS; \%), water-holding capacity 
(WHC; \%), and total porosity (TP; \%). Particle size distribution is also considered a fundamental characteristic in the physical properties of substrates because the shape, size, and density of the individual particles as well as the proportion of the different particle sizes will determine the proportion of air and water in a substrate (Handreck and Black, 2002).

Physical properties of substrates in containers will change over time as a result of the decomposition of the components caused by physical and biological degradation. The breakdown of the components generally results in lower AS, higher water retention, and increased weight of solids in the container (Ingram et al., 2003). Substrate shrinkage is also an important factor to consider when looking at the changes in physical properties over time. Nash and Pokorny (1990) defined shrinkage as the loss of bulk volume of substrates in containers, which can be attributed to the settling of fine particles into the macropores located between coarse particles. Organic matter decomposition as well as physical breakdown will also cause the substrate to shrink as the particles become smaller and fit closer together (Ingram et al., 2003). Erosion can also affect substrate shrinkage in that the substrate particles can be washed out of the container after intense rainfalls and/or irrigation depending on the particle sizes (Ingram et al., 2003).

Recommended ranges for the commercial production of nursery crops include: DBD $\left(0.19\right.$ to $\left.0.7 \mathrm{~g} \cdot \mathrm{cm}^{-3}\right)$, TP $(50 \%$ to $85 \%)$, AS ( $10 \%$ to $30 \%)$, and $\mathrm{WHC}(45 \%$ to $65 \%)$ (Yeager et al., 2007). Plant production management can be expected to be less intensive if substrates are maintained within these suggested physical property ranges (Bilderback et al., 2005); however, growers' production techniques can influence the outcomes.

Research is needed on the effect of PBH as an amendment for PB-based container substrates in the long-term production of ornamental plants. Therefore, the objectives of the study were to compare the changes in physical properties as well as the plant growth responses for the PB substrates amended with various ratios of $\mathrm{PBH}$ and to characterize how the amount of PBH affected physical properties for production of container-grown shrubs over long-term crop cycles.

\section{Materials and Methods}

Substrate formulation. A preliminary experiment was conducted to determine the lime rate required to adjust $\mathrm{PB}$ (Sun Gro Horticulture, Pine Bluff, AR; $\mathrm{pH} \approx 5.7$ ) to a $\mathrm{pH}$ similar to $\mathrm{PBH}$ (Riceland Foods, Stuttgart, $\mathrm{AR} ; \mathrm{pH} \approx 6.2$ to 6.6 ). Small batches of composted $\mathrm{PB}$ were amended with pelletized dolomitic lime (M.K. Minerals, Manhattan, $\mathrm{KS})$ at rates of $0,1.8,3.6,5.3,7.1$, and 8.9 $\mathrm{kg} \cdot \mathrm{m}^{-3}$ and were allowed to age for 2 weeks before measuring the $\mathrm{pH}$. Based on results from this experiment, a lime rate of $8.9 \mathrm{~kg} \cdot \mathrm{m}^{-3}$ was pre-plant-incorporated to all $\mathrm{PB}$.

Six media substrates were formulated by blending $\mathrm{PBH}$ with $\mathrm{pH}$-adjusted $\mathrm{PB}(\mathrm{pH}$ $\approx 6.4$ ). Individual blends with $0 \%, 20 \%, 40 \%$, $60 \%, 80 \%$, or $100 \%$ PBH (by volume) were mixed in a Mitchell Ellis 1-cubic yard soil mixer (Mitchell Ellis, Semmes, AL) on 14 Apr. 2009 and 24 Mar. 2010. Osmocote Plus (15N-3.9P-10K; 8-9 month; O.M. Scotts Horticulture Products, Marysville, $\mathrm{OH}$ ) was preplant-incorporated at a rate of $7.1 \mathrm{~kg} \cdot \mathrm{m}^{-3}$. Containers were weighed $( \pm 1 \mathrm{~g})$ using an electronic balance as they were filled to minimize variation among containers.

On 14 Apr. 2009, spirea (Spiraea $\times$ bumalda L. 'Anthony Waterer') liners (average $16-\mathrm{cm}$ tall) were potted in \#2 plastic containers [Classic 600, Nursery Supplies Inc., Chambersburg, PA; 22.2-cm (h) $\times 21.6-\mathrm{cm}$ (top diameter $) \times 17.5$-cm (bottom diameter) $]$ and $\# 5$ plastic containers [Classic 2000, Nursery Supplies Inc.; 28.2-cm (h) $\times 29.2-\mathrm{cm}$ (top diameter $) \times 24.5-\mathrm{cm}$ (bottom diameter)]. Additional containers were filled with similar substrates but were left unplanted (fallow containers) to compare changes in substrate physical properties with and without plants. Fallow containers were managed similarly as the containers with plants for the duration of the study.

The two studies with the different container sizes were placed on an outdoor (no cover) gravel area at the University of Arkansas Horticulture Research Farm (UAHRF) in Fayetteville, AR (lat. $36^{\circ} 06^{\prime} \mathrm{N}$, long. 94 ${ }^{\circ} 10^{\prime}$ $\mathrm{W}$; hardiness zone 6). One week after planting (WAP), all containers were treated with preemergent herbicide (Pendulum ${ }^{\circledR}$ 2G, pendimethalin; BASF Corp., Research Triangle Park, NC) at a rate of $224 \mathrm{~kg} \cdot \mathrm{ha}^{-1}$. The study using \#2 containers with and without the different plant species was replicated on 1 Apr. 2010 to evaluate growing season differences. The study using \#5 containers remained in the field for a 70-week period to monitor changes in physical properties as well as the plant growth differences from the individual substrates over longer production cycles. During the growing season, containers were spaced as needed to alleviate canopy overlap. Containers were placed pot-to-pot during the winter. On 13 Apr. 2010, plants grown in \#5 containers were re-fertilized (top-dressed) at a rate of $5.3 \mathrm{~kg} \cdot \mathrm{m}^{-3}$ with the same fertilizer initially applied.

Irrigation. The irrigation method varied according to the size of the containers. Irrigation for plants growing in \#2 containers was determined based on the container capacity $(\mathrm{CC})$ of the individual substrates. During the first year of the study, the amount of available water was established in a preliminary experiment using tomato (Lycopersicon esculentum Mill.) plants planted on $24 \mathrm{Feb}$ 2009 following the methods of Argo and Biernbaum (1994). The preliminary study was conducted in a climate-controlled glass greenhouse at the University of Arkansas. Plants were grown in \#2 containers with the same substrate blends used in the main experiment. On 2 May 2009, all plants were watered thoroughly and then allowed to sit for $1 \mathrm{~h}$ to establish $\mathrm{CC}$ weight. After this, no additional water was supplied to these plants.
The tomato plants were monitored twice daily to observe the first signs of visible wilt and containers with plants were weighed. The difference between the $\mathrm{CC}$ and wilt weight was used as an estimate of the total amount of available water held in the root media after irrigation.

Concurrent with the first year of the main study, a second preliminary experiment was conducted using spirea. Plants received overhead irrigation for the duration of the experiment, after which, following the same methodology previously described, the amount of available water for each container substrate was determined. The calculated value for each substrate was used as the target weight in the irrigation procedures for the \#2 containers in 2010.

From the date of planting until 15 May 2009 and 6 May 2010, plants were handwatered so the liners could get established in their containers, after which irrigation was treated independently for each root substrate treatment. Each day the decision to irrigate the substrate treatments was determined gravimetrically when the average weight of three pots reached a target weight based on a loss of more than $50 \%$ of the available water as determined in the respective preliminary experiment. Sufficient water was applied for each substrate to return containers to CC providing a 20\% leaching fraction (LF). The indicator pots were weighed before and after irrigation to determine the amount of water absorbed by the root medium. The volume of water was recorded every time water was applied. Fallow \#2 containers were overhead-irrigated whenever containers with spirea plants received water.

Number 5 containers were overhead-irrigated as needed depending on the weather conditions for the length of the experiment. Sufficient water was applied for each substrate to return containers to CC providing a $20 \%$ LF. The municipal water source (Lowell, AR) for the UAHRF had a $\mathrm{pH}$ that ranged from 6.5 to 8.5 and an alkalinity of $47 \mathrm{ppm}^{\mathrm{CaCO}_{3}}$.

Plants grown in \#5 containers were harvested on 19 Aug. 2010 (70 WAP). Plants grown in \#2 containers were harvested on 8 Oct. 2009 and 29 Sept. 2010 (25 WAP). The average daily temperatures from April to October for the first and the second years of the study were 20 and $22{ }^{\circ} \mathrm{C}$.

Physical properties: initial. Immediately after the blending process, three random samples of each substrate were collected for further analysis. Total porosity (v/v), AS (v/v), WHC $(\mathrm{v} / \mathrm{v})$, and DBD $(\mathrm{w} / \mathrm{v})$, were determined by using air-dried substrate samples. Samples were rewetted to a moisture level of $50 \%$ (w/w) and allowed to equilibrate to attain moisture uniformity. Three replicate samples of each substrate were then packed into $7.6-\mathrm{cm}$ tall by $7.6-\mathrm{cm}$ i.d. aluminum cylinder porometers. Physical properties were determined following the NCSU Porometer methods as described by Fonteno et al. (1995). Wet bulk density (WBD) was calculated by dividing the wet weight of each substrate sample by the core volume. Substrate shrinkage was 
determined by measuring the difference in substrate height (centimeters from the top of the container to the substrate surface measured in four locations per container) at $1 \mathrm{WAP}$ and again at harvest. Shrinkage is reported as a percent decrease from its original height.

Initial physical properties for each experiment were analyzed separately. Variables for the study using \#5 containers were subject to mean separation among substrates. For the study using \#2 containers, the same variables were analyzed as a $6 \times 2$ factorial with six substrates and two years (2009 and 2010) in a completely randomized design. Results were subjected to the analysis of variance (ANOVA) procedure and means were separated using Tukey's honestly significance difference (HSD).

Physical properties: final. Root medium samples were collected from each container by manually separating the roots from the substrate. Three replicate samples of each substrate were obtained by mixing the substrate from two containers together. Each replicate sample was used for physical property measurements following the same procedures used for initial measurements.

The process of removing substrates from the roots and further preparing them for analysis involved very vigorous handling of the substrates. It was therefore surprising to find in substrates with $40 \%$ or more $\mathrm{PBH}$, "aggregates" of $\mathrm{PBH}$ particles. However, while preparing substrates for physical properties analysis, we used substrate samples with no "aggregates." Samples of "aggregates" analyzed under a dissecting microscope revealed what looked like fungal hyphae. Samples were plated by a plant pathologist in the Department of Plant Pathology at the University of Arkansas and determined to belong to the genera Mucor, Trichoderma, and Fusarium.

Although samples from undisturbed substrate-filled containers were not used to determine final physical properties, the analysis of the substrates that remained in the containers for the duration of the studies were used as an indicator of how the physical properties of the components changed over time compared with how they were initially. The final physical properties of the substrates discussed in this article are not representative of the physical properties in the containers after 70 and 25 weeks under nursery production conditions.

Final physical properties (including shrinkage) for $\# 5$ containers were analyzed as a $6 \times 2$ factorial with six substrates and two planting methods (with plants or fallow containers). Final physical properties for \#2 containers were analyzed as a $6 \times 2 \times 2$ factorial with six substrates, two planting methods, and 2 years (2009 and 2010). Both studies consisted of three substrate replications per treatment combination $(\mathrm{n}=3)$ arranged in a completely randomized design. Data were subjected to ANOVA and means were separated by Tukey's HSD.

Because initial data were not specific for a given planting method, significance for the change in physical properties over time was based on a $95 \%$ confidence interval (CI). The change over time was obtained by subtracting the final value from its respective initial value. If a CI did not overlap with zero, then a significant change over time was considered.

Plant measurement and evaluation. Initial plant width (average of the plant width measured in two directions) and height was recorded at 1 WAP. Final plant width and height were recorded before harvesting and a growth index (GI) calculated. This index was calculated by the formula $\pi \times \mathrm{h} \times r^{2}$, where $\mathrm{h}$ is shoot height and $r$ is calculated by multiplying $1 / 2$ times the mean of two diameter measurements taken at a $90^{\circ}$ angle from each other. At harvest, the stems were cut at the substrate surface and dried in a forced-air oven $\left(40^{\circ} \mathrm{C}\right)$ for $96 \mathrm{~h}$ and recorded as shoot dry weight (SDW). Subsequently, substrate was separated from the roots and the roots dried in a forced-air oven $\left(40^{\circ} \mathrm{C}\right)$ for $96 \mathrm{~h}$ and recorded as root dry weight (RDW). Plant growth (GI, SDW, and RDW) was analyzed by plant species in a perfect Latin square design with each of the substrates appearing once in each row and once in each column for a total of 36 containers. Two growing seasons (2009 and 2010) were analyzed for plants growing in \#2 containers. Six single plant replications were used for each substrate. Data were analyzed using a multiple comparison of means at $\alpha=0.05$ with Tukey's HSD and the ANOVA procedure. All data were analyzed with JMP 8 (SAS Institute, Inc., Cary, NC).

\section{Results and Discussion}

\section{No. 5 containers}

Substrate physical properties. Significance for main effects and the interaction among factors related to shrinkage, TP, AS, WHC, and DBD are shown in Table 1. Shrinkage was greater in fallow containers $(32 \mathrm{~cm})$ than in containers with plants $(14$ $\mathrm{cm})$. The lower substrate shrinkage observed when plants were present has already been reported for wood-based substrates by Jackson et al. (2009), who suggested it is likely a result of plant roots filling the substrate voids created by decomposition and thus preventing the loss of volume by microbial degradation.

Total porosity in the initial blends was greatest in substrates with $40 \%$ to $100 \% \mathrm{PBH}$ and TP in those same blends was above the recommended range $(50 \%$ to $85 \%$; Yeager et al., 2007) (Table 2). In substrates with $40 \%$ to $80 \% \mathrm{PBH}$, TP significantly decreased over the 70 weeks regardless of the planting method. A significantly lower TP was observed in blends containing 20\% $\mathrm{PBH}$ when plants were present compared with fallow containers. Otherwise, the presence of plants did not alter the TP of the substrates. At 70 WAP, $\mathrm{TP}$ in fallow containers with up to $40 \% \mathrm{PBH}$ and containers with plants with up to $80 \% \mathrm{PBH}$ fell within the range suggested by Yeager et al. (2007).

In the initial blends, AS increased as the percentage of PBH increased (Table 2). Overall, AS decreased significantly over time. Except for substrate with $80 \% \mathrm{PBH}$, AS over the 70 weeks of the experiment was unaffected by planting method. The suggested range for AS in container substrates is $10 \%$ to $30 \%$ (Yeager et al., 2007). Initially, all substrates that contained $\mathrm{PBH}$ in the blends had AS percentages above the acceptable range. However, at $70 \mathrm{WAP}$, fallow containers with up to $60 \% \mathrm{PBH}$ and containers with plants with up to $40 \% \mathrm{PBH}$ fell within the recommended range.

In the initial blends, WHC decreased as the percentage of PBH increased (Table 2); that trend was generally unaffected after 70 weeks regardless of the planting method. In general, WHC significantly increased over time. Fallow containers with $60 \%$ and $80 \%$ $\mathrm{PBH}$ resulted in greater WHC than containers with plants; otherwise, the presence of plants did not alter WHC for the different substrates. The suggested range for WHC of substrates used in containers is $45 \%$ to $65 \%$ (Yeager et al., 2007). Initially, substrates with $40 \%$ or more PBH had WHC percentages below that range; however, at $70 \mathrm{WAP}$, fallow containers with up to $80 \% \mathrm{PBH}$ and containers with plants with up to $60 \% \mathrm{PBH}$ fell within the recommended range, suggesting an increase in WHC over time with the addition of $\mathrm{PBH}$ to the blends.

Dry bulk density in the initial blends decreased as the percentage of PBH increased (Table 2). Dry bulk density significantly decreased over time for substrates with $0 \%$ and $20 \% \mathrm{PBH}$ regardless of the planting method. Except for fallow containers with $20 \% \mathrm{PBH}$, DBD for each substrate was unaffected by planting method. The ideal DBD range is 0.19 to $0.70 \mathrm{~g} \cdot \mathrm{cm}^{-3}$ (Yeager et al., 2007). By this standard, initial substrates with $40 \%$ or more PBH had a DBD below the ideal range. At 70 WAP, only substrates with no addition of $\mathrm{PBH}$ fell within the lower margin of the recommended range.

Although WBD is not commonly reported as a physical property for container production, growers typically handle containers when wet and could benefit from knowing WBD

Table 1. Analysis of variance for physical properties of pine bark substrates amended with parboiled rice hulls 70 weeks after planting in \#5 containers with and without (fallow) spirea plants.

\begin{tabular}{|c|c|c|c|c|c|}
\hline Source & Shrinkage & $\mathrm{TP}$ & AS & WHC & DBD \\
\hline Planting method $^{\mathrm{z}}$ & $* * *$ & $* * *$ & NS & $* *$ & NS \\
\hline Substrate & NS & $* * *$ & $* * *$ & $* * *$ & $* * *$ \\
\hline Planting method $\times$ substrate & NS & $*$ & $* * *$ & $* * *$ & ** \\
\hline
\end{tabular}

zPlanting method $=$ with plants or fallow containers.

$\mathrm{TP}=$ total porosity; AS = air-filled pore space; $\mathrm{WHC}=$ water-holding capacity; $\mathrm{DBD}=$ dry bulk density $* * *, * *, *$, NS indicate statistical significance at the $0.001,0.01$, and $0.05 P$ level and non-significant, respectively. 
Table 2. Total porosity (TP), air-filled pore space (AS), water-holding capacity (WHC), and dry bulk density (DBD) of pine bark (PB) substrates amended with parboiled rice hulls (PBH) initially and 70 weeks after planting (final) in \#5 containers with and without (fallow) spirea plants in Fayetteville, $\mathrm{AR}_{.}^{\mathrm{z}, \mathrm{y}, \mathrm{x}, \mathrm{w}, \mathrm{v}}$

\begin{tabular}{|c|c|c|c|}
\hline \multirow{3}{*}{$\begin{array}{l}\text { Substrate } \\
(\% \mathrm{~PB}: \mathrm{PBH})^{\mathrm{u}}\end{array}$} & \multirow[b]{3}{*}{ Initial TP $(\%)$} & \multicolumn{2}{|c|}{ Final TP $(\%)$} \\
\hline & & \multicolumn{2}{|c|}{ Planting method $^{\mathrm{t}}$} \\
\hline & & Fallow & $\overline{\text { Containers with plants }}$ \\
\hline $100: 0$ & $79.7 \mathrm{~b}^{\mathrm{s}}$ & $78.0 \mathrm{fg}$ & 78.4 efg \\
\hline $80: 20$ & $83.2 \mathrm{~b}$ & 82.0 cdef & $76.4 \mathrm{~g} *$ \\
\hline $60: 40$ & $90.3 \mathrm{a}$ & 84.1 bcd* $^{*}$ & 78.8 defg* \\
\hline $40: 60$ & $94.7 \mathrm{a}$ & $87.5 \mathrm{abc}^{*}$ & 83.8 bcde* \\
\hline $20: 80$ & $95.2 \mathrm{a}$ & $88.5 \mathrm{ab}^{*}$ & $85.4 \mathrm{bc}^{*}$ \\
\hline $0: 100$ & $93.7 \mathrm{a}$ & $91.6 \mathrm{a}$ & $91.8 \mathrm{a}$ \\
\hline
\end{tabular}

\begin{tabular}{|c|c|c|c|}
\hline \multirow{3}{*}{$\begin{array}{l}\text { Substrate } \\
(\% \text { PB:PBH })^{u}\end{array}$} & \multirow[b]{3}{*}{ Initial AS (\%) } & \multicolumn{2}{|c|}{ Final AS (\%) } \\
\hline & & \multicolumn{2}{|c|}{ Planting method ${ }^{\mathrm{t}}$} \\
\hline & & Fallow & Containers with plants \\
\hline $100: 0$ & $26.5 \mathrm{c}^{\mathrm{s}}$ & $12.9 \mathrm{~g}^{*}$ & $15.7 \mathrm{~g}^{*}$ \\
\hline $80: 20$ & $35.5 \mathrm{c}$ & $24.4 \mathrm{ef}^{*}$ & $17.2 \mathrm{fg}^{*}$ \\
\hline $60: 40$ & $46.0 \mathrm{~b}$ & $27.1 \mathrm{de}^{*}$ & $27.1 \mathrm{de}^{*}$ \\
\hline $40: 60$ & $54.1 \mathrm{~b}$ & $27.0 \mathrm{de}^{*}$ & $31.7 \mathrm{~cd}^{*}$ \\
\hline $20: 80$ & $66.0 \mathrm{a}$ & $37.7 c^{*}$ & $45.9 b^{*}$ \\
\hline $0: 100$ & $70.6 \mathrm{a}$ & $63.2 \mathrm{a} *$ & $58.0 \mathrm{a} *$ \\
\hline
\end{tabular}

\begin{tabular}{lccc} 
& & \multicolumn{2}{c}{ Final WHC (\%) } \\
\cline { 3 - 4 } $\begin{array}{l}\text { Substrate } \\
(\% \text { PB:PBH })^{\mathrm{u}}\end{array}$ & \multicolumn{2}{c}{ Planting method $^{\mathrm{u}}$} & \multicolumn{2}{c}{ Fallow } & Containers with plants $^{\mathrm{Initial} \mathrm{WHC}(\%)}$ \\
\cline { 3 - 4 } $100: 0$ & $53.2 \mathrm{a}^{\mathrm{s}}$ & $65.0 \mathrm{a}^{*}$ & $62.6 \mathrm{a}^{*}$ \\
$80: 20$ & $47.7 \mathrm{~b}$ & $57.7 \mathrm{abc}$ & $59.2 \mathrm{ab}^{*}$ \\
$60: 40$ & $44.3 \mathrm{bc}$ & $57.0 \mathrm{abc}$ & $51.7 \mathrm{bc}^{*}$ \\
$40: 60$ & $40.6 \mathrm{c}$ & $60.5 \mathrm{a}^{*}$ & $52.1 \mathrm{bc}^{*}$ \\
$20: 80$ & $29.3 \mathrm{~d}$ & $50.8 \mathrm{c}^{*}$ & $39.4 \mathrm{~d}^{*}$ \\
$0: 100$ & $23.1 \mathrm{e}$ & $28.3 \mathrm{e}$ & $33.7 \mathrm{de}^{*}$
\end{tabular}

\begin{tabular}{lccc} 
& & \multicolumn{2}{c}{ Final DBD $\left(\mathrm{g} \cdot \mathrm{cm}^{-3}\right)$} \\
\cline { 3 - 4 } $\begin{array}{l}\text { Substrate } \\
(\% \mathrm{~PB}: \mathrm{PBH})^{\mathrm{u}}\end{array}$ & \multicolumn{2}{c}{ Planting method $^{\mathrm{t}}$} & Containers with plants \\
\cline { 3 - 4 } & Initial DBD $\left(\mathrm{g} \cdot \mathrm{cm}^{-3}\right)$ & $0.19 \mathrm{a}^{*}$ & $0.19 \mathrm{a}^{*}$ \\
$80: 20$ & $0.21 \mathrm{a}^{\mathrm{s}}$ & $0.17 \mathrm{~b}$ & $0.18 \mathrm{a}^{*}$ \\
$60: 40$ & $0.19 \mathrm{~b}$ & $0.16 \mathrm{~b}$ & $0.16 \mathrm{~b}$ \\
$40: 60$ & $0.17 \mathrm{c}$ & $0.14 \mathrm{c}$ & $0.14 \mathrm{~cd}$ \\
$20: 80$ & $0.14 \mathrm{~d}$ & $0.13 \mathrm{de}$ & $0.12 \mathrm{e}$ \\
$0: 100$ & $0.11 \mathrm{e}$ & $0.10 \mathrm{f}$ & $0.10 \mathrm{f}$ \\
\hline
\end{tabular}

${ }^{\mathrm{z}}$ Data collected from three samples per substrate and represented as means. Analysis performed using the North Carolina State University Porometer Method (Fonteno et al., 1995).

${ }^{y}$ Total porosity is WHC + AS. Suggested range for TP is 50\% to $85 \%$ (Yeager et al., 2007).

${ }^{\mathrm{x}} \mathrm{AS}$ is the volume of water drained from sample $\div$ volume of sample. Suggested range for AS is $10 \%$ to $30 \%$ (Yeager et al., 2007).

${ }^{\text {wWHC }}$ is (wet weight - oven dry weight) $\div$ volume of the sample. Suggested range for WHC is $45 \%$ to $65 \%$ (Yeager et al., 2007).

${ }^{\mathrm{V}} \mathrm{DBD}$ after forced-air drying at $105^{\circ} \mathrm{C}$ for $48 \mathrm{~h}$. Suggested range for DBD is 0.19 to $0.70 \mathrm{~g} \cdot \mathrm{cm}^{-3}(\mathrm{Yeager}$ et al., 2007).

uSubstrates were individual blends of PB amended with $0 \%, 20 \%, 40 \%, 60 \%, 80 \%$, or $100 \% \mathrm{PBH}(\mathrm{v} / \mathrm{v})$. 'Means followed by the same letter are not significantly different based on Tukey's honestly significant difference test $(P=0.05)$.

sMeans within column followed by the same letter are not significantly different based on Tukey's honestly significant difference test $(P=0.05)$.

*Indicates difference from its respective initial value $(P=0.05)$.

values. Initial WBD was highest in substrates with $0 \% \mathrm{PBH}\left(0.83 \mathrm{~g} \cdot \mathrm{cm}^{-3}\right)$ and decreased as $\mathrm{PBH}$ increased in the blends with $100 \% \mathrm{PBH}$ resulting in the lowest WBD $\left(0.41 \mathrm{~g} \cdot \mathrm{cm}^{-3}\right)$. The trend was generally the same at $70 \mathrm{WAP}$, which could suggest that amending PB substrates with $\mathrm{PBH}$ contributes to a lower container weight and thus may make handling of wet containers easier. However, no recommended range has been established for WBD.

Although it is not always clearly indicated, we assume that most of the research conducted on substrates analyzes the physical properties on what we consider initial samples (samples that have not been exposed
Initial results for the physical properties of substrates suggested that in general, as $\mathrm{PBH}$ increased in the blends, TP and AS increased and consequently, WHC and DBD decreased. Similar results had already been reported by Evans and Gachukia (2007) when amending sphagnum peat-based substrates with $\mathrm{PBH}$. They suggested that substrates containing up to $30 \% \mathrm{PBH}$ had physical properties within the recommended ranges of container substrates, which is close to our results for the initial physical properties of the PB-based substrates.

When looking at the final physical properties (70 WAP), results suggested a general decrease in TP and AS and consequently, an increase in WHC over time. These results are similar to those reported for pine tree substrates after 70 weeks of growing cotoneaster (Cotoneaster horizontalis Decne. var. perpusillis C. K. Shneid.) under nursery conditions (Jackson et al., 2009). Changes in physical properties over time are related to the breakdown of the particles that reduce the AS within the substrate, thereby increasing its WHC.

After 70 weeks, substrates with up to $60 \%$ PBH had physical properties that were generally within the sufficiency ranges used in container production as suggested by Yeager et al. (2007). Similar to our results, AllaireLeung et al. (1999) studying peat substrates found that the changes in physical properties that best related to the growth of Prunus $\times$ cistena (Hansen) Koehne did not necessarily deteriorate over the 14 months of their study but rather maintained or even improved.

Plant growth. Substrates with $40 \%$ or less $\mathrm{PBH}$ yielded plants with the largest GI (Table $3)$. There was a negative relationship between the percentage of $\mathrm{PBH}$ and SDW. Root dry weight generally decreased as the percentage of $\mathrm{PBH}$ increased in the blend. The general decrease in plant GI with an increase in $\mathrm{PBH}$ is supported by Holcomb et al. (2008), who reported that increasing the percentage of $\mathrm{PBH}$ in a peatmoss blend reduced the growth for sunflower. Dueitt and Newman (1994) also reported a decrease in plant height and dry weight for four greenhouse-grown bedding plants with a $40 \%$ to $50 \%$ replacement of vermiculite with either fresh or composted rice hulls in a sphagnum peat-based substrate. Plant growth could have also been affected by the low cation exchange capacity (CEC) of PBH (less than 1 meq/100 g; Kuczmarski, 1994) compared with PB (6.3 to $9.9 \mathrm{meq} / 100 \mathrm{~g}$; Tucker, 1995), which suggests that PBH particles are less likely to retain some nutrients than PB and might be reflected in a decrease in growth. experiments are of a short duration $(\approx 5$ to 9 weeks; Altland and Krause, 2009; Boyer et al., 2008; Fain et al., 2008); therefore, physical properties are not expected to change over the short growing period. For the purpose of this research, the analyses were performed on samples used at potting and at harvest 70 weeks later to evaluate if the properties had changed after being exposed to nursery production cycles and if they remained within the acceptable ranges for container nursery production.

\section{No. 2 containers}

Substrate physical properties. Significant effects for the interaction among factors related to shrinkage, TP, AS, WHC, and DBD are shown in Table 4 . The substrate with the least shrinkage was $0 \% \mathrm{PBH}(6 \%)$ and this was significantly different from $100 \% \mathrm{PBH}$ $(9 \%)$. During the experiment, we observed significant losses of PBH from the container drainage holes and from the substrate surface 
resulting from blowing wind. From a grower's standpoint, this volume loss, which is different from the typical breakdown process, would not be considered a problem.
Total porosity in the initial blends was highest in substrates with $40 \%$ or more $\mathrm{PBH}$, and these values were above the recommended range (50\% to $85 \%$; Yeager et al., 2007)
Table 3. Effect of pine bark (PB) substrates amended with parboiled rice hulls (PBH) on growth of spirea grown in \#5 containers for 70 weeks in Fayetteville, AR.

\begin{tabular}{lccc}
\hline $\begin{array}{l}\text { Substrate } \\
(\% \text { PB:PBH })^{\mathrm{z}}\end{array}$ & $\begin{array}{c}\text { Growth index } \\
\left(\mathrm{cm}^{3} \times 10^{4}\right)^{\mathrm{y}}\end{array}$ & Shoot dry wt $(\mathrm{g})$ & Root dry wt $(\mathrm{g})$ \\
\hline $100: 0$ & $1.7 \mathrm{a}^{\mathrm{x}}$ & $157 \mathrm{a}$ & $199 \mathrm{a}$ \\
$80: 20$ & $1.7 \mathrm{a}$ & $130 \mathrm{~b}$ & $166 \mathrm{abc}$ \\
$60: 40$ & $1.7 \mathrm{a}$ & $118 \mathrm{bc}$ & $162 \mathrm{abc}$ \\
$40: 60$ & $1.2 \mathrm{~b}$ & $97 \mathrm{~cd}$ & $127 \mathrm{cde}$ \\
$20: 80$ & $0.9 \mathrm{~b}$ & $69 \mathrm{de}$ & $105 \mathrm{def}$ \\
$0: 100$ & $0.7 \mathrm{~b}$ & $39 \mathrm{e}$ & $67 \mathrm{f}$ \\
\hline
\end{tabular}

${ }^{z}$ Substrates were individual blends of PB amended with $0 \%, 20 \%, 40 \%, 60 \%, 80 \%$, or $100 \%$ PBH (v/v). ${ }^{\mathrm{y}}$ Growth index $=\pi \times \mathrm{h} \times r^{2}$, where $\mathrm{h}$ is shoot height and $r$ is calculated by multiplying $1 / 2$ times the mean of two diameter measurements taken at a $90^{\circ}$ angle from each other.

${ }^{x}$ Means within column followed by the same letter are not significantly different based on Tukey's honestly significant difference test $(P=0.05)$.

Table 4. Analysis of variance for physical properties of pine bark substrates amended with parboiled rice hulls 25 weeks after planting in \#2 containers for two growing seasons (2009 and 2010) with and without spirea plants.

\begin{tabular}{|c|c|c|c|c|c|}
\hline & Shrinkage & $\mathrm{TP}$ & AS & WHC & DBD \\
\hline Year & $* * *$ & $* * *$ & NS & $* * *$ & NS \\
\hline Planting method ${ }^{\mathrm{z}}$ & NS & NS & NS & NS & NS \\
\hline Year $\times$ planting method & NS & $*$ & $* * *$ & $* * *$ & $*$ \\
\hline Substrate & $*$ & $* * *$ & $* * *$ & $* * *$ & $* * *$ \\
\hline Year $\times$ substrate & NS & $*$ & $* *$ & NS & NS \\
\hline Planting method $\times$ substrate & NS & $* *$ & NS & NS & NS \\
\hline Year $\times$ planting method $\times$ substrate & NS & $* *$ & $* *$ & NS & NS \\
\hline
\end{tabular}

zPlanting method $=$ with plants or fallow containers.

$\mathrm{TP}=$ total porosity; $\mathrm{AS}=$ air-filled pore space; $\mathrm{WHC}=$ water-holding capacity; $\mathrm{DBD}=$ dry bulk density. $* * *, * * *$, NS indicate statistical significance at the $0.001,0.01$, and $0.05 P$ level and non-significant, respectively.

Table 5. Total porosity (TP) and air-filled pore space (AS) of pine bark (PB) substrates amended with parboiled rice hulls $(\mathrm{PBH})$ initially and 25 weeks after planting (final) in \#2 containers for two growing seasons with and without (fallow) spirea plants in Fayetteville, AR.,y,x

\begin{tabular}{|c|c|c|c|c|c|}
\hline \multirow[b]{3}{*}{$\begin{array}{l}\text { Substrate } \\
(\% \text { PB:PBH })^{w}\end{array}$} & \multirow[b]{3}{*}{ Initial TP (\%) } & \multicolumn{4}{|c|}{ Final TP $(\%)^{\mathrm{v}}$} \\
\hline & & \multicolumn{2}{|c|}{2009} & \multicolumn{2}{|c|}{2010} \\
\hline & & Fallow & $\begin{array}{l}\text { Containers } \\
\text { with plants }\end{array}$ & Fallow & $\begin{array}{l}\text { Containers } \\
\text { with plants }\end{array}$ \\
\hline $100: 0$ & $81.5 \mathrm{~b}^{\mathrm{u}}$ & $83.6 \mathrm{efgh}^{* \mathrm{u}}$ & $78.5 \mathrm{~h}$ & $83.0 \mathrm{fgh}$ & $83.0 \mathrm{fgh}$ \\
\hline $80: 20$ & $85.1 \mathrm{~b}$ & $84.7 \mathrm{efg}$ & $80.8 \mathrm{gh}$ & 87.4 cdef & 87.9 bcdef \\
\hline $60: 40$ & $90.6 \mathrm{a}$ & 88.7 bcde & 85.7 defg* & 87.7 bcdef* & $91.4 \mathrm{abc}$ \\
\hline $40: 60$ & $94.4 \mathrm{a}$ & 88.2 bcdef* & 90.9 abcd* & 90.6 abcd $^{*}$ & $92.3 \mathrm{abc}$ \\
\hline $20: 80$ & $93.8 \mathrm{a}$ & 88.5 bcdef & $90.8 \mathrm{abcd}$ & $95.9 \mathrm{a}^{*}$ & $93.1 \mathrm{ab}$ \\
\hline \multirow[t]{3}{*}{$0: 100$} & $92.8 \mathrm{a}$ & $94.6 \mathrm{a}$ & $90.8 \mathrm{abcd}^{*}$ & $94.8 \mathrm{a}$ & $93.0 \mathrm{ab}^{*}$ \\
\hline & & \multicolumn{4}{|c|}{ Final AS $(\%)^{\mathrm{v}}$} \\
\hline & & \multicolumn{2}{|c|}{2009} & \multicolumn{2}{|c|}{2010} \\
\hline $\begin{array}{l}\text { Substrate } \\
(\% \text { PB:PBH })^{w}\end{array}$ & Initial AS (\%) & Fallow & $\begin{array}{l}\text { Containers } \\
\text { with plants }\end{array}$ & Fallow & $\begin{array}{l}\text { Containers } \\
\text { with plants }\end{array}$ \\
\hline $100: 0$ & $24.0 \mathrm{e}^{\mathrm{u}}$ & $20.5 \mathrm{jkh}^{\mathrm{u}}$ & $13.1 \mathrm{mn}^{*}$ & $12.6 \mathrm{n}^{*}$ & $16.21 \mathrm{mn} *$ \\
\hline $80: 20$ & $34.0 \mathrm{~d}$ & $22.8 \mathrm{ijkl} *$ & $19.7 \mathrm{klm} *$ & $22.5 \mathrm{ijkl} *$ & $27.0 \mathrm{hij}$ \\
\hline $60: 40$ & $43.7 \mathrm{c}$ & $35.0 \mathrm{fg}^{*}$ & 29.2 ghi* & 24.7 ijk* & $31.5 \mathrm{gh}^{*}$ \\
\hline $40: 60$ & $55.1 \mathrm{~b}$ & $47.1 \mathrm{de}$ & $41.9 \mathrm{e}^{*}$ & 41.6 ef* & $45.6 \mathrm{e}^{*}$ \\
\hline $20: 80$ & $66.1 \mathrm{a}$ & $53.9 \mathrm{~cd}^{*}$ & $53.3 \mathrm{~cd}^{*}$ & $55.6 \mathrm{bc} *$ & $53.5 \mathrm{~cd}^{*}$ \\
\hline $0: 100$ & $69.7 \mathrm{a}$ & $66.6 \mathrm{a}$ & $62.0 \mathrm{ab}$ & $63.2 \mathrm{a}^{*}$ & $63.3 \mathrm{a}^{*}$ \\
\hline
\end{tabular}

${ }^{\mathrm{z} D a t a}$ collected from three samples per substrate and represented as means. Analysis performed using the North Carolina State University Porometer Method (Fonteno et al., 1995).

${ }^{\mathrm{y}}$ Total porosity is water-holding capacity + AS. Suggested range for TP is $50 \%$ to $85 \%$ (Yeager et al., 2007).

${ }^{\mathrm{x}} \mathrm{AS}$ is the volume of water drained from sample $\div$ volume of sample. Suggested range for AS is $10 \%$ to $30 \%$ (Yeager et al., 2007).

${ }^{\mathrm{w}}$ Substrates were individual blends of PB amended with $0 \%, 20 \%, 40 \%, 60 \%, 80 \%$, or $100 \% \mathrm{PBH}$ (v/v). 'Means followed by the same letter are not significantly different based on Tukey's honestly significant difference test $(P=0.05)$.

"Means within column followed by the same letter are not significantly different based on Tukey's honestly significant difference test $(P=0.05)$.

*Indicates difference from its respective initial value $(P=0.05)$.
(Table 5). For each year, planting method had no effect on the final TP for each substrate. In general, TP for each planting method was not different between years. In 2009, final TP for substrates with up to $20 \% \mathrm{PBH}$ fell within the suggested range regardless of the planting method. However, results for 2010 showed that only substrates with no PBH were within the range as recommended by Yeager et al. (2007).

In the initial blends, AS increased as the percentage of $\mathrm{PBH}$ increased; the trend was the same at 70 WAP (Table 5). Final AS showed a general decrease over time. Except for substrate with $0 \% \mathrm{PBH}$ in 2009 and $40 \% \mathrm{PBH}$ in 2010, final AS was unaffected by the presence of plants. Air-filled pore space for fallow containers with $0 \%$ and $40 \% \mathrm{PBH}$ was significantly greater in 2009 than 2010 . Conversely, containers with plants with $20 \% \mathrm{PBH}$ had a greater AS in 2010 than 2009. Initially, all substrates amended with PBH fell above the recommended range for AS (10\% to $30 \%$; Yeager et al., 2007). However, results suggested that at 25 WAP, substrates with up to $40 \% \mathrm{PBH}$ were within or above the suggested range for container substrates.

In the initial blends, WHC was negatively correlated to an increase in $\mathrm{PBH}$; the trend was the same at 25 WAP (Table 6). Overall, WHC increased over time. Initially, substrates

Table 6. Water-holding capacity (WHC) and dry bulk density (DBD) of pine bark (PB) substrates amended with parboiled rice hulls $(\mathrm{PBH})$ initially and 25 weeks after planting (final) in \#2 containers averaged over two growing seasons (2009 and 2010) with and without (fallow) spirea plants in Fayetteville, AR. ${ }^{z, y, x}$

\begin{tabular}{lcc}
\hline $\begin{array}{l}\text { Substrate } \\
(\% \text { PB:PBH) }\end{array}$ & \multicolumn{2}{c}{ WHC (\%) } \\
\cline { 2 - 3 } 100:0 & Initial & Final \\
$80: 20$ & $57.5 \mathrm{a}^{\mathrm{v}}$ & $66.4 \mathrm{a}^{*}$ \\
$60: 40$ & $51.2 \mathrm{~b}$ & $62.2 \mathrm{~b}^{*}$ \\
$40: 60$ & $46.9 \mathrm{c}$ & $58.3 \mathrm{c}^{*}$ \\
$20: 80$ & $39.3 \mathrm{~d}$ & $46.5 \mathrm{~d}^{*}$ \\
$0: 100$ & $27.8 \mathrm{e}$ & $38.0 \mathrm{e}^{*}$ \\
& $23.1 \mathrm{f}$ & $29.5 \mathrm{f}^{*}$ \\
Substrate & \multicolumn{2}{c}{ DBD $\left(\mathrm{g} \cdot \mathrm{cm}^{-3}\right)$} \\
$(\%$ PB:PBH) & Initial & Final \\
\hline $100: 0$ & $0.22 \mathrm{a}^{\mathrm{v}}$ & $0.19 \mathrm{a}^{*}$ \\
$80: 20$ & $0.20 \mathrm{~b}$ & $0.17 \mathrm{ab}^{*}$ \\
$60: 40$ & $0.17 \mathrm{c}$ & $0.17 \mathrm{~b}$ \\
$40: 60$ & $0.15 \mathrm{c}$ & $0.13 \mathrm{c}^{*}$ \\
$20: 80$ & $0.12 \mathrm{~d}$ & $0.11 \mathrm{c}$ \\
$0: 100$ & $0.11 \mathrm{~d}$ & $0.09 \mathrm{~d}$ \\
\hline
\end{tabular}

${ }^{\mathrm{z}}$ Data collected from three samples per substrate and represented as means. Analysis performed using the North Carolina State University Porometer Method (Fonteno et al., 1995).

${ }^{\mathrm{y}} \mathrm{WHC}$ is (wet weight - oven dry weight) volume of the sample. Suggested range for WHC is $45 \%$ to $65 \%$ (Yeager et al., 2007).

${ }^{\mathrm{x}} \mathrm{DBD}$ after forced-air drying at $105^{\circ} \mathrm{C}$ for $48 \mathrm{~h}$. Suggested range for DBD is 0.19 to $0.70 \mathrm{~g} \cdot \mathrm{cm}^{-3}$ (Yeager et al., 2007).

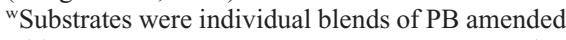
with $0 \%, 20 \%, 40 \%, 60 \%, 80 \%$, or $100 \% \mathrm{PBH}(\mathrm{v} / \mathrm{v})$. vMeans within column followed by the same letter are not significantly different based on Tukey's honestly significant difference test $(P=0.05)$.

*Indicates difference from its respective initial value $(P=0.05)$. 
with $40 \%$ or less $\mathrm{PBH}$ were within the recommended range for WHC ( $45 \%$ to $65 \%$; Yeager et al., 2007). However, at 25 WAP, substrates with up to $60 \% \mathrm{PBH}$ were within the range.

Dry bulk density in the initial blends decreased with the increase of PBH (Table 6). Dry bulk density significantly decreased at 25 WAP in substrates with $0 \%, 20 \%$, and $60 \% \mathrm{PBH}$. Initially, substrates with up to $20 \% \mathrm{PBH}$ fell within the recommended range for DBD (0.19 to $0.70 \mathrm{~g} \cdot \mathrm{cm}^{-3}$; Yeager et al., 2007); however, at $25 \mathrm{WAP}$, only substrates with $0 \% \mathrm{PBH}$ remained within this recommended range, suggesting that containers with high proportions of $\mathrm{PBH}$ could be considered too light to be used under nursery conditions. Additionally, under windy conditions, we observed tipping over of the containers regardless of the substrate used.

The general variations in physical properties between years could be attributed to differences in the PBH batches used to make the substrate blends. In the fall of 2009, and before obtaining the PBH used in 2010, the manufacturing process for PBH was adjusted (S. Johnson, personal communication, 2009). This may be responsible for variations between years. Parboiled rice hulls had a higher percentage of coarse particles in 2010 than 2009.

Plant growth and water uptake -2009 and 2010. Results for the two growing seasons suggested that increasing the percentage of $\mathrm{PBH}$ resulted in a general trend of decreasing GI for spirea (Table 7). Shoot dry weight and root mass for spirea indicated no substrateby-year interaction; therefore, data were combined for the 2 years. Shoot dry weight was significantly greater in substrates with up to $40 \% \mathrm{PBH}$ and decreased as the percentage of $\mathrm{PBH}$ increased in the remaining blends. Root mass followed the same general trend as GI or SDW in that RDW decreased as the percentage of $\mathrm{PBH}$ increased. Our results are comparable to those reported by Lee et al. (2000) who noted that the growth of pepper seedlings decreased in substrates containing fresh rice hulls. Evans and Gachukia (2004) reported a decrease in plant growth for several greenhouse crops when comparing equivalent percentages of $\mathrm{PBH}$ to perlite as an amendment to peat-based substrates; however, plants produced from all blends were of marketable quality at the end of the experiment.

In summary, these results support the general conclusion obtained from the previous study in which spirea plants were grown for 70 weeks in \#5 containers. Both studies conclude that spirea plants grown in PB-based substrates amended with up to $40 \% \mathrm{PBH}$ have similar growth (GI, SDW, and RDW) as those grown in substrates containing $0 \% \mathrm{PBH}$ and are of marketable quality.

The average number of irrigation events after the plants were established in the substrates (20 weeks) ranged from 36 to 66 (Table 8 ). There was a noticeable increase in the number of irrigation events when substrates exceeded $80 \%$ PBH. In this study, the cumulative volume (CV) consisted of the volume of water required to return the substrates to CC plus a $20 \% \mathrm{LF}$. The greatest CV

Table 7. Effect of pine bark (PB) substrates amended with parboiled rice hulls (PBH) on the growth of spirea grown in \#2 containers for 25 weeks for two growing seasons in Fayetteville, AR.

\begin{tabular}{|c|c|c|c|c|}
\hline \multirow{2}{*}{$\begin{array}{l}\text { Substrate } \\
(\% \text { PB:PBH })^{z}\end{array}$} & \multicolumn{2}{|c|}{ Growth index $\left(\mathrm{cm}^{3} \times 10^{3}\right)^{x, y}$} & \multirow[b]{2}{*}{ Shoot dry wt (g) } & \multirow[b]{2}{*}{ Root dry wt (g) } \\
\hline & 2009 & 2010 & & \\
\hline 100:0 & $4.3 \mathrm{a}$ & 2.8 bcde & $39 \mathrm{a}^{\mathrm{w}}$ & $80 \mathrm{a}^{\mathrm{w}}$ \\
\hline $80: 20$ & $3.2 \mathrm{abc}$ & $3.3 \mathrm{ab}$ & $35 \mathrm{a}$ & $69 \mathrm{ab}$ \\
\hline $60: 40$ & $2.4 \mathrm{bcdef}$ & $2.9 \mathrm{bcd}$ & $33 \mathrm{a}$ & $64 \mathrm{~b}$ \\
\hline $40: 60$ & $2.0 \mathrm{cdef}$ & $1.8 \mathrm{def}$ & $25 \mathrm{~b}$ & $54 \mathrm{bc}$ \\
\hline $20: 80$ & $1.7 \mathrm{ef}$ & $1.4 \mathrm{fg}$ & $21 \mathrm{~b}$ & $47 \mathrm{c}$ \\
\hline $0: 100$ & $1.5 \mathrm{fg}$ & $5.0 \mathrm{~g}$ & $13 \mathrm{c}$ & $40 \mathrm{c}$ \\
\hline
\end{tabular}

${ }^{2}$ Substrates were individual blends of PB amended with $0 \%, 20 \%, 40 \%, 60 \%, 80 \%$, or $100 \%$ PBH (v/v). ${ }^{\mathrm{y}}$ Growth index $=\pi \times \mathrm{h} \times r^{2}$, where $\mathrm{h}$ is shoot height and $r$ is calculated by multiplying $1 / 2$ times the mean of two diameter measurements taken at a $90^{\circ}$ angle from each other.

${ }^{x}$ Means followed by the same letter are not significantly different based on Tukey's honestly significant difference test $(P=0.05)$.

"Means within column followed by the same letter are not significantly different based on Tukey's honestly significant difference test $(P=0.05)$.

Table 8. Number of water applications and cumulative water requirements of pine bark (PB) substrates amended with parboiled rice hulls $(\mathrm{PBH})$ on the growth of spirea grown in $\# 2$ containers averaged over two growing seasons in Fayetteville, AR. ${ }^{\mathrm{z}}$

Substrate

\begin{tabular}{llll}
$(\% \mathrm{~PB}: \mathrm{PBH})^{\mathrm{y}}$ & No. of irrigations & Cumulative volume (L) & Volume/irrigation (L) \\
\hline 100.0 &
\end{tabular}

$\begin{array}{cccc}100: 0 & 36 & 38 & 1.1\end{array}$

$\begin{array}{llll}80: 20 & 36 & 38 & 1.1\end{array}$

$\begin{array}{llll}60: 40 & 39 & 36 & 0.9\end{array}$

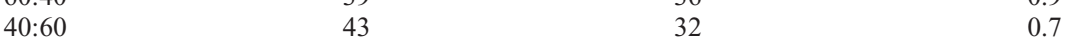

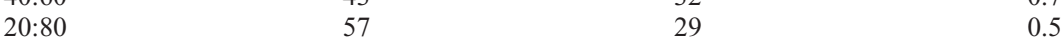

$\begin{array}{rrrr}0: 100 & 66 & 36 & 0.5\end{array}$

${ }^{\mathrm{z}}$ Data includes water application over 20 weeks. The two growing seasons were 2009 and 2010. ${ }^{\mathrm{y}}$ Substrates were individual blends of PB with $0 \%, 20 \%, 40 \%, 60 \%, 80 \%$, or $100 \% \mathrm{PBH}(\mathrm{v} / \mathrm{v})$.

was observed in substrates with $0 \%$ and $20 \%$ PBH (38 L). However, the volume of water applied per irrigation generally decreased as the proportion of $\mathrm{PBH}$ increased. Although we anticipated that the $\mathrm{CV}$ required to irrigate substrates with $100 \% \mathrm{~PB}$ and $100 \% \mathrm{PBH}$ would be different, they were essentially similar (38 versus 36 ). However, the number of irrigations increased $83 \%$ when substrates contained 100\% PBH compared with 100\% PB.

A study evaluating different rates of recycled paper as an amendment to PB described differences in the water requirements as related to the WHC of the substrates (Craig and Cole, 2000). Although they did not report final number of water applications and CV, they mentioned that the substrate with the greatest WHC received fewer irrigation events but more water per irrigation to maintain a similar CC among substrates. This is similar to our results in that as the WHC of the substrates decreased, the number of irrigations increased and the volume of water per irrigation decreased.

\section{Conclusions}

Based on the plant growth measurements made in this study, PB substrates that are amended with up to $40 \% \mathrm{PBH}$ will not result in a decrease in plant growth or increase the volume or frequency of irrigation for the production of container-grown spirea over one (25 weeks) and two (70 weeks) growing seasons. Substrates with more than $60 \% \mathrm{PBH}$ resulted in reduced plant growth and an increase in the number of irrigation events. A reduction in plant growth when using high percentages of $\mathrm{PBH}$ may involve more than one factor. In general, as the percentage of PBH was increased above $40 \%$, physical properties such as AS, WHC, and TP fell outside of recommended ranges. Although substrate CEC was not measured in this study, the lower CEC of $\mathrm{PBH}$ relative to $\mathrm{PB}$ may also contribute to the reduction in growth.

Overall, as the percentages of PBH increased in PB-based blends, the TP and AS increased, whereas the WHC and DBD decreased. Physical properties of substrates amended with $\mathrm{PBH}$ improved over time with TP and AS decreasing and WHC increasing. Based on our results, PB-based substrates amended with up to $40 \% \mathrm{PBH}$ retained physical properties that were generally within current guidelines for nursery container substrates after one and two growing seasons.

Parboiled rice hulls, which have not previously been investigated as an amendment for bark-based container media in long-term nursery crop production, appear to be an acceptable substrate amendment for PB. However, another consideration when amending $\mathrm{PB}$ with another component is the cost of amending substrates. As of May 2010, the free on board (FOB) price for PBH was $\$ 21 /$ yard $^{3}$ (Jonesboro, AR). In Arkansas, the FOB price for PB was \$33/yard ${ }^{3}$ (Plumerville, AR). A cost-benefit analysis must be performed by growers that do not already have blending machinery in place as well as considering additional storage and blending costs.

\section{Literature Cited}

Allaire-Leung, S.E., J. Caron, and L.E. Parent. 1999. Changes in physical properties of peat 
substrates during plant growth. Can. J. Soil Sci. 79:137-139.

Altland, J.E. and C.R. Krause. 2009. Use of switchgrass as a nursery container substrate. HortScience. 44:1861-1865.

Argo, W.R. and J.A. Biernbaum. 1994. Irrigation requirements, root medium $\mathrm{pH}$, and nutrient concentrations of Easter lilies grown in five peat-based media with and without an evaporation barrier. J. Amer. Soc. Hort. Sci. 119:11511156.

Baiyeri, K.P. 2005. Response of Musa species to macro-propagation. II: The effects of genotype, initiation and weaning media on sucker growth and quality in the nursery. Afr. J. Biotechnol. 4:229-234.

Bilderback, T.E., S.L. Warren, J.S. Owen, Jr., and J.P. Albano. 2005. Healthy substrates need physicals too! HortTechnology 15:9-13.

Boyer, C., J.S. Owen, Jr., and J. Altland. 2010. Development of sustainable and alternative substrates for nursery container crops. Proc. Southern Nursery Assoc. Research Conf. 55: $410-412$.

Boyer, C.R., G.B. Fain, C.H. Gilliam, T.V. Gallagher, H.A. Torbert, and J.L. Sibley. 2008. Clean chip residual: A substrate component for growing annuals. HortTechnology 18:423-432.

Buck, J.S. 2008. The use of ground parboiled fresh rice hulls as an alternative horticultural root substrate component for containerized greenhouse crop production. $\mathrm{PhD}$ diss., University of Arkansas, Fayetteville, AR.

Buck, J.S. and M.R. Evans. 2010. Physical properties of ground parboiled fresh rice hulls used as a horticultural root substrate. HortScience 45:643-649.

Bunt, A.C. 1988. Media and mixes for containergrown plants: A manual on the preparation and use of growing pot plants. 2nd Ed. Unwin Hyman Ltd., London, UK.

Cole, D.M., J.L. Sibley, E.K. Blythe, D.J. Eakes, and K.M. Tilt. 2005. Effect of cotton gin compost on substrate properties and growth of Azalea under differing irrigation regimes in a greenhouse setting. HortTechnology 15:145-148.

Craig, P.B. and J.C. Cole. 2000. Recycled paper as a growth substrate for container Spirea production. HortScience 35:1253-1257.

Day, M. 2009. Mulch producers tune into biofuel boom. Soil Mulch Producers News 3:1-3, 16. 2 Sept. 2010. <http://soilandmulchproducernews. com/archives/50-januaryfebruary-2009/117mulch-producers-tune-into-biofuel-boom>.

Dueitt, S. and S.E. Newman. 1994. Physical analysis of fresh and aged rice hulls used as a peat moss substitute in greenhouse media. Proc. Southern Nursery Assoc. Research Conf. 39:81-85.

Einert, A.E. 1972. Performance of rice hull media for pot Easter lilies under three forcing systems. HortScience 7:60-61.
Einert, A.E. and G. Guidry. 1975. Rice hulls and hull compost in growing media for containergrown junipers. Ark. Farm Res. 24:2.

Evans, M.R. and M.M. Gachukia. 2004. Fresh parboiled rice hulls serve as an alternative to perlite in greenhouse crop substrates. HortScience. 39:232-235.

Evans, M.R. and M.M. Gachukia. 2007. Physical properties of sphagnum peat-based root substrates amended with perlite or parboiled fresh rice hulls. HortTechnology 17:312-315.

Fain, G.B., C.H. Gilliam, J.L. Sibley, and C.R. Boyer. 2008. Whole tree substrates derived from three species of pine in production of annual vinca. HortTechnology 18:13-17.

Fonteno, W.C., C.T. Hardin, and J.P. Brewster. 1995. Procedures for determining physical properties of horticultural substrates using the NCSU Porometer. Horticultural Substrates Laboratory, North Carolina State University, Raleigh, NC.

Guerrero, L., J.M. Gascó, and L. HernándezApaolaza. 2002. Use of pine bark and sewage sludge compost as components of substrates for Pinus pinea and Cupressus arizonica production. J. Plant Nutr. 25:129-141.

Handreck, K. and N. Black. 2002. Growing media for ornamental plants and turf. 3rd Ed. University New South Wales Press, Sydney, Australia.

Haynes, R.W. 2003. An analysis of the timber situation in the United States: 1952-2050. Gen. Tech. Rept. PNWGTR- 560. U.S. Department of Agriculture, Forest Service, Pacific Northwest Research Station, Portland, OR.

Holcomb, J., A. Michael, S. Lenhart, and J. Rowe. 2008. The potential for rice hulls. Greenhouse Product News 8:29-32.

Ingram, D.L., W.H. Richard, and H.Y. Thomas. 2003. Growth media for container grown ornamental plants. Florida Coop. Ext. Serv. University of Florida, Bul. 241

Jackson, B.E. 2008. Chemical, physical, and biological factors influencing nutrient availability and plant growth in a pine tree substrate. PhD diss., Virginia Polytechnic Institute \& State University, Blacksburg, VA.

Jackson, B.E., A.M. Wright, D.M. Cole, and J.L. Sibley. 2005. Cotton gin compost as a substrate component in container production or ornamental plants. J. Environ. Hort. 23:118-122.

Jackson, B.E., R.D. Wright, and J.R. Seiler. 2009. Changes in chemical and physical properties of pine tree substrate and pine bark during longterm nursery crop production. HortScience 44 : 791-799.

Juliano, B., C. Maningat, and C. Pascual. 1987. Properties of fraction of rice hull. Phytochem. 26:3261-3263.

Kämpf, A.N. and M. Jung. 1991. The use of carbonized rice hulls as an horticultural substrate. Acta Hort. 294:271-283.
Kuczmarski, D. 1994. Amending the cost of media. Amer. Nurseryman 179:47-52.

Laiche, A.J., Jr. and V.E. Nash. 1990. Evaluation of composted rice hulls and a lightweight clay aggregate as components of container-plant growth media. J. Environ. Hort. 8:14-18.

Lee, J.-W., B.-Y. Lee, Y.B. Lee, and K.-S. Kim. 2000. Growth and inorganic element contents of hot pepper seedlings in fresh and decomposed expanded rice hull-based substrates. J. Kor. Soc. Hort. Sci. 41:147-151.

Lovelace, W. and D. Kuczmarski. 1992. The use of composted rice hulls in rooting and potting media. Comb. Proc. Intl. Plant Prop. Soc. 42: 449-450.

Lu, W., J.L. Sibley, C.H. Gilliam, J.S. Bannon, and Y. Zhang. 2006. Estimation of U.S. bark generation and implications for horticultural industries. J. Environ. Hort. 24:29-34.

Nash, M.A. and F.A. Pokorny. 1990. Shrinkage of selected two-component container media. HortScience. 28:930-931.

Nelson, P.V. 2003. Greenhouse operation and management. 6th Ed. Prentice-Hall, Upper Saddle River, NJ.

Owings, A.D. 1993. Cotton gin trash as a medium component in production of 'Golden Bedder' coleus. Proc. Southern Nursery Assoc. Research Conf. 38:65-66.

Papafotiou, M., J. Chronopoulos, G. Kargas, M. Voreakou, N. Leodaritis, O. Lagogiani, and S. Gazi. 2001. Cotton gin trash compost and rice hulls as growing medium components for ornamentals. J. Hort. Sci. Biotechnol. 76:431-435.

Sambo, P., F. Sannazzaro, and M.R. Evans. 2008. Physical properties of ground fresh rice hulls and sphagnum peat used for greenhouse root substrates. HortTechnology 18:384-388.

Tatum, D. and N. Winter. 1997. Rice Hull Ash as a potting substrate for bedding plants. Proc. Southern Nursery Assoc. Research Conf. 42: 121-122.

Tucker, R.M. 1995. Chemical characteristics of pine bark. Nursery Notes 29:17.

Tyler, H.H., S.L. Warren, T.E. Bilderback, and W.C. Fonteno. 1993. Composted turkey litter: II. Effect on plant growth. J. Environ. Hort. 11: 137-141.

Wright, R.D. and J.F. Browder. 2005. Chipped pine logs: A potential substrate for greenhouse and nursery crops. HortScience 40:1513-1515.

Wright, R.D., J.F. Browder, and B.E. Jackson. 2006. Ground pine chips as a substrate for container-grown woody nursery crops. J. Environ. Hort. 24:181-184.

Yeager, T.H., D.C. Fare, J. Lea-Cox, J. Ruter, T.E. Bilderback, C.H. Gilliam, A.X. Niemiera, S.L. Warren, T.E. Whitwell, R.D. Wright, and K.M. Tilt. 2007. Best management practices: Guide for producing nursery crops. 2nd Ed. Southern Nurserymen's Assoc., Marietta, GA. 